\title{
Estimation of additive and epistatic gene effects of doubled haploid lines of winter oilseed rape (Brassica napus $\mathbf{L}$.)
}

\author{
Jan Bocianowski · Kamila Nowosad · Agnieszka Dobrzycka · Joanna Wolko
}

Received: 23 March 2017 / Accepted: 27 April 2017/Published online: 11 May 2017

(C) The Author(s) 2017. This article is an open access publication

\begin{abstract}
In this paper 60 doubled haploid lines of oilseed rape (Brassica napus L.) were studied. Genetic parameters as additive and epistasis effects were estimated for nine quantitative traits. The results indicate the importance of both additive and epistasis gene effects of number of branches per plant, number of siliques per plant, number of seeds per silique and silique length in this study.
\end{abstract}

Keywords Additive effect - Doubled haploid (DH) lines · Epistasis · Oilseed rape

Edited by Roland Kölliker, Richard G. F. Visser, Achim Walter \& Beat Boller

J. Bocianowski $(\square)$

Department of Mathematical and Statistical Methods, Poznań University of Life Sciences, Wojska Polskiego 28, 60-637 Poznań, Poland e-mail: jboc@up.poznan.pl

K. Nowosad

Department of Genetics, Plant Breeding and Seed Production, Wroclaw University of Environmental and Life Sciences, Grunwaldzki 24A, 53-363 Wrocław, Poland

\section{A. Dobrzycka · J. Wolko}

Department of Oilseed Crops, Plant Breeding and Acclimatization Institute-National Research Institute, Strzeszyńska 36, 60-479 Poznań, Poland

\section{Introduction}

Doubled haploid (DH) lines are used in many studies in rapeseed, because their production is the fastest way to obtain homozygous populations (Cegielska-Taras et al. 2015). DH lines carry a homogeneous DNA, what is useful in phenotyping and genotyping studies (Chen et al. 2007; Radoev et al. 2008). In DHs production only one cycle of recombination takes place, what makes easier to track parents genes in the offspring (Pink et al. 2008).

In order to plan an efficient breeding program, the knowledge of the nature, magnitude of gene effects and their input to the control of metric traits, as well as the association among yield and yield-related traits are required (Bocianowski et al. 2016). To determine the genetic background of quantitative traits in segregating populations of Brassica napus, quantitative trait loci (QTLs) analyses were applied (Cai et al. 2014). In the genome of oilseed rape a lot of QTLs and epistatic interactions were discovered, many of which had pleiotropic effects (Udall et al. 2006; Basunanda et al. 2010).

The inheritance of quantitative traits is a very complex issue, because they are the result not only of the activity of multiple individual genes, but also by the interactions between them. In purpose to estimate the parameters components for plants, several genetic statistical models have been developed (Mather and Jinks 1982; Kearsey and Pooni 1996). Gene action of quantitative traits can be evaluated by generation 
mean analysis, e.g. parental, $\mathrm{F}_{1}, \mathrm{~F}_{2}, \mathrm{BC}_{1}$. However, more effective estimation of additive and epistasis effects is on the basis of homozygous lines (Bocianowski 2012a, 2013, 2014; Bocianowski and Nowosad 2015; Kim et al. 2015; Monnahan and Kelly 2015; Ober et al. 2015).

The purpose of this study was estimation of the parameters connected with the additive and additiveby-additive interaction (epistasis) gene action.

\section{Materials and methods}

\section{Plant material}

Plant material used in the paper includes $60 \mathrm{DH}$ lines derived from crossing between line $324 / 2$ as a female parent (high oleic acid content, 77.9\%) and line 622/3 as a male parent (high oil content, $51.9 \%$; high seed yield).

\section{Field experiments}

Field experiment was conducted in Borowo $\left(52^{\circ} 70^{\prime} \mathrm{N}\right.$, $\left.16^{\circ} 46^{\prime} \mathrm{E}\right)$, Plant Breeding Strzelce Ltd., Co.-IHARPIB Group in growing season 2014/15. It had a randomized blocks design with three replications. Each plot contains four rows $2 \mathrm{~m}$ long. Distance between rows was $30 \mathrm{~cm}$. The field management followed standard agricultural practice.

Traits evaluated in the field trial were: duration of flowering, flowering time, plant height, number of branches per plant, number of siliques per plant, silique length, number of seeds per silique, 1000 seed weight, and oil content in seeds. More detailed description of phenotyping in Dobrzycka et al. (2016).

\section{Statistical analyses}

The normality of distribution of the traits was tested using Shapiro-Wilk's normality test and having normally distributed traits, it was assumed that the data followed the multivariate normal distribution. The one-way analysis of variance (ANOVA) was carried out to determine the effects of DH lines on the variability of studied traits. The relationships between observed traits were estimates using Pearson correlation coefficients.
Estimation of the genetic parameters

Estimation of the additive gene effect and additive-byadditive interaction of homozygous loci (epistasis) effect on the basis of phenotypic observations requires identification of groups of extreme DH lines, i.e. lines with the minimal and maximal expression of the observed trait (Choo and Reinbergs 1982). The group of minimal lines consists of the lines which contain, theoretically, only alleles reducing the value of the trait. Analogously, the group of maximal lines contains the lines which have only alleles increasing the trait value. In this paper we identify the groups of extreme lines using the quantile method (Bocianowski et al. 1999), in which lines with the mean values smaller (bigger) than 0.03 (0.97) quantile of the empirical distribution of means are assumed as minimal (maximal) lines. The choose the quantiles 0.03 and 0.97 is results of previously study (Bocianowski et al. 1999). The total additive effect $a$ of all genes controlling the trait and the total additive-byadditive interaction effect $a a$ may be estimated by the formulas (Bocianowski and Krajewski 2009; Bocianowski 2012b):

$\hat{a}=\frac{1}{2}\left(\bar{L}_{\max }-\bar{L}_{\min }\right)$

and

$\hat{a a}=\frac{1}{2}\left(\bar{L}_{\max }+\bar{L}_{\min }\right)-\bar{L}$,

where $\bar{L}_{\min }$ and $\bar{L}_{\max }$ denote the means for the groups of minimal and maximal DH lines, respectively, and $\bar{L}$ denotes the mean for all DH lines. The test statistics to verified hypotheses about genetic parameters different than zero are given by

$F_{a}=\frac{M S_{a}}{M S_{e}}$ and $F_{a a}=\frac{M S_{a a}}{M S_{e}}$,

where $M S_{a}$ denote mean square for parameter $a$, $M S_{a a}$-mean square for epistasis $a a, M S_{e}$-mean square for residual.

\section{Results and discussion}

All studied traits have a normal distribution. Analysis of variance indicates that the main effects of DH lines was significant $(P<0.001)$ for all the traits of study. 
Table 1 shows a correlation matrix for the observed traits. Plant height was correlated with flowering time and oil content in seeds; number of branches per plant was correlated with number of siliques per plant, flowering time and oil content in seeds; silique length was correlated with number of seeds per silique, flowering time and oil content in seeds. All statistically significant correlation coefficients were positive (Table 1). Many important traits are positively or negatively correlated, because they are controlled by some of the same genes or because they are developmentally or structurally related.

Estimates of additive gene action effects based on DH lines were significantly larger than zero only for plant height, number of branches per plant, number of siliques per plant, number of seeds per silique, duration of flowering and silique length (Table 2). Estimates of epistatic effects were statistically significant for number of branches per plant, number of siliques per plant, number of seeds per silique, 1000 seed weight and silique length (Table 2).

Table 1 The Pearson correlation coefficients matrix for the nine traits

\begin{tabular}{|c|c|c|c|c|c|c|c|c|}
\hline Trait & $\begin{array}{l}\text { Flowering } \\
\text { time }\end{array}$ & $\begin{array}{l}\text { Plant } \\
\text { height }\end{array}$ & $\begin{array}{l}\text { Number of } \\
\text { branches per } \\
\text { plant }\end{array}$ & $\begin{array}{l}\text { Number of } \\
\text { siliques per } \\
\text { plant }\end{array}$ & $\begin{array}{l}\text { Silique } \\
\text { length }\end{array}$ & $\begin{array}{l}\text { Number of } \\
\text { seeds per } \\
\text { silique }\end{array}$ & $\begin{array}{l}1000 \\
\text { seed } \\
\text { weight }\end{array}$ & $\begin{array}{l}\text { Oil } \\
\text { content in } \\
\text { seeds }\end{array}$ \\
\hline $\begin{array}{c}\text { Duration of } \\
\text { flowering }\end{array}$ & -0.230 & 0.061 & -0.05 & 0.088 & -0.15 & -0.073 & -0.050 & 0.130 \\
\hline Flowering time & & $0.416 * * *$ & $0.257 *$ & 0.196 & $0.332 * *$ & 0.194 & -0.150 & 0.203 \\
\hline Plant height & & & 0.069 & 0.083 & 0.223 & 0.051 & 0.240 & $0.382 * *$ \\
\hline $\begin{array}{l}\text { Number of } \\
\text { branches per } \\
\text { plant }\end{array}$ & & & & $0.689 * * *$ & 0.115 & -0.006 & -0.190 & $0.342 * *$ \\
\hline $\begin{array}{l}\text { Number of } \\
\text { siliques per } \\
\text { plant }\end{array}$ & & & & & 0.188 & -0.098 & -0.240 & 0.201 \\
\hline Silique length & & & & & & $0.338 * *$ & -0.090 & $0.405^{* *}$ \\
\hline $\begin{array}{l}\text { Number of } \\
\text { seeds per } \\
\text { silique }\end{array}$ & & & & & & & -0.156 & 0.104 \\
\hline $\begin{array}{l}1000 \text { seed } \\
\text { weight }\end{array}$ & & & & & & & & 0.122 \\
\hline
\end{tabular}

Table 2 Estimates of additive and epistasis effects for observed traits of doubled haploid lines

\footnotetext{
$* \mathrm{P}<0.05$

$* * \mathrm{P}<0.01$
}

\begin{tabular}{|c|c|c|c|}
\hline \multirow[t]{2}{*}{ Trait } & \multicolumn{2}{|l|}{ Estimates of } & \multirow[t]{2}{*}{ Mean value } \\
\hline & Additive effect, $a$ & Epistasis effect, $a a$ & \\
\hline Duration of flowering & $2.75^{*}$ & 0.400 & 24.35 \\
\hline Flowering time & 4.00 & 1.533 & 117.47 \\
\hline Plant height & $18.35^{*}$ & -0.450 & 146.85 \\
\hline Number of branches per plant & $3.50 * *$ & $0.552 * *$ & 10.17 \\
\hline Number of siliques per plant & $197.95 * * *$ & $29.157 * *$ & 434.84 \\
\hline Silique length & $14.86 * *$ & $3.204 * *$ & 59.29 \\
\hline Number of seeds per silique & $4.86 * *$ & $0.797 * *$ & 14.80 \\
\hline 1000 seed weight & 0.53 & $0.108 *$ & 5.28 \\
\hline Oil content in seeds & 3.67 & 0.438 & 43.28 \\
\hline
\end{tabular}


Estimation of genetic parameters has a significant role in winter oilseed rape breeding. The result indicates the importance of both additive and epistasis gene effects of number of branches per plant, number of siliques per plant, number of seeds per silique and silique length in this study. The presence of epistasis has important implication for any breeding program. Statistically significant epistasis effect and non-significant additive effect for 1000 seed weight means that this trait was probably determined by genes with small individual effects but strong gene-by-gene interaction effects. Confounding epistatic effects in models suggested that inheritance of these traits is complex and polygenic. Epistasis has been reported for many traits in a number of crops: barley (Bocianowski et al. 2016); maize ( $\mathrm{Li}$ et al. 2016); rice (Matsubara et al. 2015), and wheat (Jaiswal et al. 2016).

Open Access This article is distributed under the terms of the Creative Commons Attribution 4.0 International License (http:// creativecommons.org/licenses/by/4.0/), which permits unrestricted use, distribution, and reproduction in any medium, provided you give appropriate credit to the original author(s) and the source, provide a link to the Creative Commons license, and indicate if changes were made.

\section{References}

Basunanda P, Radoev M, Ecke W, Friedt W, Becker HC, Snowdon RJ (2010) Comparative mapping of quantitative trait loci involved in heterosis for seedling and yield traits in oilseed rape (Brassica napus L.). Theor Appl Genet 120:271-281

Bocianowski J (2012a) A comparison of two methods to estimate additive-by-additive interaction of QTL effects by a simulation study. J Theor Biol 308:20-24

Bocianowski J (2012b) Analytical and numerical comparisons of two methods of estimation of additive $x$ additive interaction of QTL effects. Scientia Agricola 69(4):240-246

Bocianowski J (2013) Epistasis interaction of QTL effects as a genetic parameter influencing estimation of the genetic additive effect. Genet Mol Biol 36(1):93-100

Bocianowski J (2014) Estimation of epistasis in doubled haploid barley populations considering interactions between all possible marker pairs. Euphytica 196:105-115

Bocianowski J, Krajewski P (2009) Comparison of the genetic additive effect estimators based on phenotypic observations and on molecular marker data. Euphytica 165:113-122

Bocianowski J, Nowosad K (2015) Mixed linear model approaches in mapping QTLs with epistatic effects by a simulation study. Euphytica 202:459-467

Bocianowski J, Krajewski P, Kaczmarek Z (1999) Comparison of methods of choosing extreme doubled haploid lines for genetic parameter estimation. Colloq Biometrycze 29:193-202 (in Polish)

Bocianowski J, Górczak K, Nowosad K, Rybiński W, Piesik D (2016) Path analysis and estimation of additive and epistatic gene effects of barley SSD lines. J Integr Agric 15(9):1983-1990

Cai D, Xiao Y, Yang W, Ye W, Wang B, Younas M, Wu J, Liu K (2014) Association mapping of six yield-related traits in rapeseed (Brassica napus L.). Theor Appl Genet 127:85-96

Cegielska-Taras T, Szała L, Matuszczak M, Babula-Skowrońska D, Mikołajczyk K, Popławska W, Sosnowska K, Hernacki B, Olejnik A, Bartkowiak-Broda I (2015) Doubled haploids as a material for biotechnological manipulation and as a modern tool for breeding oilseed rape (Brassica napus L.). Biotechnologia 96(1):7-18

Chen W, Zhang Y, Liu X, Chen B, Tu J, Fu T (2007) Detection of QTL for six yield-related traits in oilseed rape (Brassica napus) using $\mathrm{DH}$ and immortalized $\mathrm{F}_{2}$ populations. Theor Appl Genet 115:849-858

Choo TM, Reinbergs E (1982) Estimation of the number of genes in doubled haploid populations of barley (Hordeum vulgare). Can J Genet Cytol 24:337-341

Dobrzycka A, Wolko J, Bocianowski J, Nowosad K (2016) Phenotypic variation of yield related traits in DH lines and hybrids of winter oilseed rape (Brassica napus L.). Rośliny Oleiste Oilseed Crops 37:37-52

Jaiswal V, Gahlaut V, Meher PK, Mir RR, Jaiswal JP, Rao AR, Balyan HS, Gupta RR (2016) Genome wide single locus single trait, multi-locus and multi-trait association mapping for some important agronomic traits in common wheat $(T$. aestivum L.). PLoS ONE 11(7):e0159343. doi:10.1371/ journal.pone.0159343

Kearsey MJ, Pooni HS (1996) The genetical analysis of quantitative traits, 1st edn. Chapman and Hall, London, p 381

Kim HH, Kim DM, Kang JM, Lee HS, Kang YJ, Ahn SN (2015) Analysis of QTL interaction for grain weight using near isogenic lines in rice. Plant Breed Biotechnol 3(1):30-38

Li C, Li Y, Shi Y, Song Y, Zhang D, Buckler EB, Zhang Z, Li Y (2016) Analysis of recombination QTLs, segregation distortion, and epistasis for fitness in maize multiple populations using ultra-high-density markers. Theor Appl Genet 129:1775-1784

Mather K, Jinks JL (1982) Biometrical genetics, 3rd edn. Chapman and Hall, London, p 396

Matsubara K, Yamamoto E, Mizobuchi R, Yonemaru J, Yamamoto T, Kato H, Yano M (2015) Hybrid breakdown caused by epistasis-based recessive incompatibility in a cross of rice (Oryza sativa L.). J Hered 106:113-122

Monnahan PJ, Kelly JK (2015) Epistasis is a major determinant of the additive genetic variance in Mimulus guttatus. PLoS Genet 11(5):e1005201. doi:10.1371/journal.pgen.1005201

Ober U, Huang W, Magwire M, Schlather M, Simianer H, Mackay TFC (2015) Accounting for genetic architecture improves sequence based genomic prediction for a drosophila fitness trait. PLoS ONE 10(5):e0126880. doi:10. 1371/journal.pone.0126880

Pink D, Bailey L, McClement S, Hand P, Mathas E, BuchananWollaston V, Astley D, King G, Teakle G (2008) Double haploids, markers and QTL analysis in vegetable brassicas. Euphytica 164:509-514 
Radoev M, Becker HC, Ecke W (2008) Genetic analysis of heterosis for yield and yield components in rapeseed (Brassica napus L.) by quantitative trait locus mapping. Genetics 179:1547-1558
Udall JA, Quijada PA, Lambert B, Osborn TC (2006) Quantitative trait analysis of seed yield and other complex traits in hybrid spring rapeseed (Brassica napus L.): 2. identification of alleles from unadapted germplasm. Theor Appl Genet 113:597-609 